Díaz Velázquez, Yunuen .

Filiación, en su caso: Académica de la Universidad Autónoma de Morelos, Facultad de Artes, Departamento de Teoría e Historia del Arte.

\title{
SEXUALIDAD 2.0.
}

\author{
TIPO DE TRABAJO
}

Comunicación

PALABRAS CLAVE

arte contemporáneo, sexualidad, fotografía, postprivacidad, web.

\section{KEY WORDS}

Contemporary art, sexuality, photography, post-privacy, web.

\section{RESUMEN}

¿Cómo han cambiado las dinámicas del erotismo y la sexualidad en el mundo virtual? El fotógrafo Evan Baden aborda el tema en su serie Technically Intimate, una serie en la que explora las poses más utilizadas en el sexting (envío de contenido erótico o pornográfico a través de los teléfonos móviles). Su serie muestra a jóvenes estadounidenses semidesnudas en sus recámaras, utilizando un teléfono para tomar sus fotos. Esas fotos muestran cómo la sexualidad que pertenecía al ámbito de lo privado, poco a poco se convierte en un lugar público. ¿Nos encontraremos en una época de postorgía como lo propondría Baudrillard? Mi ponencia pretende ahondar en este tema a partir del análisis de la serie fotográfica de Evan Baden.

\section{ABSTRACT}

¿How have the dynamics of eroticism and sexuality changed in the virtual world? Photographer Evan Baden addresses the issue in his series "Technically Intimate", a series in which he explores the most used poses in sexting (sending erotic or pornographic content through mobile phones). His series shows scantily clad young Americans in their rooms, using a phone to take pictures. These pictures show how sexuality that belonged to the private sphere gradually becomes a public place. ¿Will we meet at a time of post orgy as Baudrillard proposed? My paper aims to delve into this subject from analysis of photographic series of Evan Baden.

\section{CONTENIDO}

We demand that images and videos be transmitted from one private space to another. To be enjoyed now, and forever to come.

EVAN BADEN

El ojo parpadea y su mecánica pupila ha captado la imagen, sólo hay que dar un click sobre el ícono "send" y ya está: sexualidad 2.0. Producción erótica instantánea. La intimidad de una recámara, un teléfono celular conectado a la web y una persona dispuesta a generar un afrodisiaco visual, son todo lo necesario para poner en marcha este sistema contemporáneo de autoexpresión: 
ser cada vez más sensual, ser cada vez más visto, ser deseado, flotar en el universo virtual tan sólo como imagen, irrepetible y eterno, recuerdo del instante: vanitas frente al espejo, brillando en la pantalla de un dispositivo móvil.

La serie de Evan Baden Technically intimate, realizada entre los años 2008 y 2010 en Inglaterra, nos muestra a jóvenes adolescentes en la intimidad de sus recámaras practicando sexting. Este fenómeno cuyo nombre proviene de la conjunción de las palabras sex y texting, se refiere a la tendencia a compartir contenidos eróticos o pornográficos mediante teléfonos móviles, tabletas o cualquier otro aparato digital. Si bien, se dice que comenzó a través de los mensajes SMS y en formato de escritura, con la proliferación de las cámaras se convirtió en un fenómeno visual. Se le ha ubicado sobre todo como una tendencia entre adolescentes, aunque se ha extendido a muchas otras edades que han encontrado las bondades de la exploración web.

Las primeras notas sobre el fenómeno aparecen alrededor de 2005 en Gran Bretaña, pero es un fenómeno que se ha identificado a nivel mundial, no necesariamente por influencia del primer mundo, sino al parecer, como fenómeno que refleja un nuevo ethos contemporáneo ligado al disfrute del cuerpo y el trueque de intimidad vía web: uno muestra una parte del cuerpo como mostraría una tirada en un juego de cartas, el otro responde con un gesto similar, el nudismo remoto acontece como un juego de confidencias, la intimidad que requería una construcción de confianza y una vida conjunta para el conocimiento del otro, se convierte en nuestra sociedad en un intercambio nudista, intimidad instantánea a través del desocultamiento del cuerpo. Ya no tenemos tiempo de construir relaciones afectivas profundas, de conocer y descubrir al otro poco a poco, el capitalismo con sus valores de urgencia y novedad, han desplazado estas actitudes y el conocer al otro se convierte en un ejercicio tan literal como la desnudez vía web.

Hoy más que nunca nuestra sexualidad se ha convertido en un proceso fotográfico, no nos basta con mirarnos al espejo, queremos que esa imagen perdure, en toda su festividad y belleza, en ese sentido, como diría la escritora Cristina Rivera Garza, nos encontramos muy cercanos a Pompeya: "Nuestra cuna no es ya más esa ciudad eterna donde las ruinas yacen, capa sobre capa, en un gesto de circular totalidad. Nuestra cuna es esa otra ciudad petrificada en la gloria de un instante: Pompeya. Corte. Tajo. Interrupción. Hubo, alguna vez, eso es cierto, un homo psychologicus. Se trataba de ese ser humano de las sociedades industriales que construyó gruesos muros para separar lo privado de lo público y proteger así una noción silenciosa y profunda, individual y estable, del yo. Pero el homo psychologicus ya fue. En su lugar se ha configurado el homo technologicus: un ser post-humano que habita los espacios físicos y virtuales de las sociedades informáticas para quien el yo no es ni secreto ni una hondura ni mucho menos una interioridad, sino, por el contrario, una forma de visibilidad. Conectado a digitalidades diversas, el technologicus escribe esa vida que sólo existe para que aparezca inscrita en fragmentos de circulación constante. Una extraña pero sugerente combinación entre el culto a la personalidad y una noción alterdirigida del yo dentro de un régimen de visibilidad total ha provocado que miles de seres post-humanos se lancen raudos y veloces a transmitir mensajes escritos sobre lo que les acontece en ese justo y pompéyico instante. De ahí el Twitter. De ahí, también, la nueva escritura auto/biográfica que en el papel imita la movilidad y la desaparición constante del texto en un Timeline. Leer es, en efecto, una forma de constatar. No hay secreto. (Rivera:10)

Las imágenes de Baden constatan el instante, la espontaneidad, un presente congelado para siempre en el eterno presente de la web. Efervescencia porno chic. Lo femenino aglutinado en ese espasmo de un parpadeo digital. La intimidad es cada vez un territorio menos nítido, en su lugar, todo se va convirtiendo poco a poco en una cuestión pública, en tanto, todo se hace notar, todo se presenta en la pantalla.

No sólo nos encontramos cercanos a Pompeya, sino quizás más aún, como propone Richard Sennett, a los romanos que vieron la caída de su imperio: "del mismo modo en que la podredumbre moral supuso el socavamiento del poder romano para gobernar el Occidente, se ha dicho que se ha socavado el poder moderno de Occidente para gobernar el mundo. A pesar de la simpleza de esta concepción, la misma contiene un elemento de verdad. Existe un escabroso paralelo entre la crisis de la sociedad romana con posterioridad a la muerte de Augusto y la vida moderna: se refiere al equilibrio entre la vida privada y la pública" (Senett, 1978: 11) 
Lo privado parece ir perdiendo importancia frente al acontecer de la vida en las redes sociales. "Publicar", el verbo más utilizado de estos últimos años, implica colocarse en esa marea flotante de la web, nadie quiere estar debajo del agua, el imperativo es colocarse sobre la ola más alta y mantenerse ahí. La subjetividad se materializa en las redes sociales, ya no sólo se trata de un proceso intrapsíquico, sino que es jalado al exterior por las pantallas. La máquina freudiana se ha consolidado y todos los hombres nos preguntamos quiénes somos y nos vemos obligados a contestar dicha pregunta en los formularios electrónicos. En lugares como Facebook, las personas nos vemos orilladas a revelarlo todo: estatus marital, gustos, estudios, amigos. La pregunta diaria en esta plataforma es ¿Qué estás pensando? Ni siquiera el pensamiento puede guardarse para sí. Hay que remover todas las placas, lo superfluo, llegar a lo más íntimo.

Es pornografía textual, la puesta en escena del yo, un pornoestéreo, como le llamaría Baudrillard: “Que toda palabra sea liberada, y que vaya hasta el deseo. Nos revolcamos en esta liberalización que no es sino el proceso creciente de la obscenidad. Todo lo que está escondido, y goza aún de lo prohibido, será desterrado, devuelto a la palabra y a la evidencia. Lo real crece, lo real se ensancha, un día todo el universo será real, y cuando lo real sea universal, será la muerte. Simulación porno; la desnudez nunca es un signo cualquiera. La desnudez velada por la ropa funciona como referente secreto, ambivalente. Desvelada se hace superficie como signo y entra en la circulación de los signos: desnudez design." (Baudrillard 1981: 36). En la web más que construir, se diseña la identidad, las fotografías aparentemente inocentes son teatrales, lo que aparece en ellas es el recreo del individuo en sus divertimentos falaces, pero la exterioridad no es una máscara, es el único rostro que nos queda.

Aunque quizás en otros momentos, el arte ha mostrado ya ese rostro de la pequeña burguesía recreándose en sus lujos y deseos, en eso quizás nos parecemos al arte realizado durante el rococó, recordemos el cuadro Desnudo en reposo de Francois Boucher, la joven Marie-Louis O’ Murphy se encuentra reclinada sobre un diván de terciopelo, su desnudes se disimula un poco debido a que su cuerpo se encuentra boca abajo, pero su figura se puede apreciar de la espalada a los pies desnuda, debajo del sillón, los cojines desacomodados representan cierto desenfado, mientras que una cortina de seda hace patente su estatus burgués, de no ser por la técnica, la imagen no dista tanto de las imágenes de Baden, es un espacio interior develado, la recámara íntima en la que la joven se puede permitir la desnudez más prosaica.

En las recámaras de Baden nos encontramos también con ese mismo desenfado, las sábanas están por lo general desacomodadas, la ropa acumulada en una esquina del cuarto, el desorden prima y las jóvenes no se sienten apenadas de mostrarlo. Estas imágenes que Baden muestra son recreaciones que él realiza a partir de un conjunto de imágenes que encontró en la web, después de estudiarlas y ver las poses más repetidas así como la conformación de los espacios, Baden buscó a sus modelos, también a través de la web. Sus imágenes fotográficas son reinterpretaciones de las fotos originales, son en un sentido Baudrillariano, simulacros, con ese mismo carácter de ser más reales que lo real, esto porque si en las primeras fotos que Baden colecciona, algunas chicas no sabían que habían sido publicadas, en las segundas, las modelos han accedido a aparecer conociendo el destino de dichas fotos.

¿Por qué aparecen estas chicas en sus recámaras y qué nos dice esto sobre nuestra sociedad? De hecho, en la historia del arte, encontramos muchas imágenes de mujeres recostadas en un sillón dentro de una recámara o espacio íntimo: la Venus de Tiziano, las Odaliscas de Delacroix, la Olympia de Manet, obras pintadas por hombres para su disfrute. Se trata de la mirada voyerista de la sociedad occidental que pervive en nuestro imaginario, la mujer sensual está encerrada en su recámara, no es la amazonas de la selva, no es Diana cazadora, sino un personaje burgués, una mujer que ocupa su sitio en la sociedad, es decir, en la casa, y ahí es encontrada por la mirada masculina, el sitio más prohibido, el más íntimo, éste es develado en la fotografía, las recámaras llenas de posters y afiches de las jóvenes en las fotografías de Baden reflejan su apego a las imágenes, su deseo de construirse como imagen, su ansia de ser vistas aunque sea como mero objeto de deseo. Emulando al resto de los íconos visuales femeninos que irrumpen en la vida cotidiana. 
Que las chicas descubran su belleza ante los ojos masculinos no es en realidad algo nuevo, sin embargo, el elemento distintivo es el uso del teléfono móvil, la máquina de imágenes que hace del fenómeno algo aún más visible en nuestra sociedad interconectada todo el tiempo a través de la web. La imagen fotográfica a través de la web prolifera de manera descontrolada, cualquiera puede bajarla a su dispositivo y acceder a ella, guardarla y explorarla en dónde sea y cuándo sea, además de compartirla.

La liberación sexual de los sesentas y setentas se oponía a un régimen político, a una privacidad impuesta para resguardo de los valores públicos que sustentaban al estado, pero este último ha sabido reconfigurarse bajo el mercado y aquellos atributos que representaban la rebeldía se conciben hoy como los valores dominantes en el mercado de la personalidad donde las chicas deben mostrar cada vez más su cuerpo adolescente. ¿Acaso las mujeres siguen reproduciendo los valores heteropatriarcales en los que la belleza y el deseo son los principales atributos de lo femenino?¿Se trata de lo femenino tomando control de su cuerpo y su deseo? ¿Piensan en alguna de estas cosas las jóvenes que realizan estas selfies sexuales? La respuesta es: no. Ninguna de estas jóvenes parece cuestionarse sobre estos problemas, lo instantáneo es uno de los valores de la sociedad actual que ya no necesita cuestionarse sino que se ve empujada a actuar.

Las nuevas subjetividades se perfilan hacia la extraversión, todo lo que antes se guardaban las personas para sí deberá verterse en el exterior. Son los recursos humanos de la sociedad 2.0. con su vestido transparente y brillante al estilo Rihanna. Como lo plantea Felix Stadler: "La flexibilidad, la creatividad y la expresividad son vistas hoy como rasgos personales generalmente deseables, necesarios para el éxito social y, cada vez más, como pertenecientes a la 'verdadera naturaleza' de los seres humanos...la sociabilidad en este nuevo entorno es radicalmente diferente a las formas precedentes, fundamentadas, sobre todo, en la copresencia física. Para socializarse en un espacio de flujos primero hay que hacerse visible, es decir, crear una representación a través de actos expresivos de comunicación. Para conectarse dentro de esta red, una persona tiene que ser, al mismo tiempo, sutilmente diferente, o sea, creativa dentro de alguna tendencia reconocible, y someterse a las convenciones sociales que mantienen unida a una red particular. Hay, al mismo tiempo, aspectos negativos y positivos en el hacerse visible de esta manera: está la amenaza de ser invisible, ignorado y anulado, por una parte, y por otra, la promesa de crear una red social que realmente exprese la propia individualidad" (Félix Stalder:2014).

La subjetividad se ve obligada a convertirse en fenómeno público, si es que se espera tener éxito social, por ello el lente de los teléfonos móviles se vuelve cada vez más importante y las personas están dispuesta a hacer buenas inversiones en estos aparatos.

Como conclusión puedo decir que en la sociedad de la web, la imagen es lo que interconecta a las personas, es en ella en la que se expresa la personalidad de los individuos, por tanto, es ella la que provoca o no, que se produzcan lazos afectivos entre individuos, la imagen sexual del sexting tiene el propósito de crear un lazo de intimidad, una complicidad que genere cierta afectividad entre un par de individuos, sin embargo, en la era de la web, no hay espacios para lo privado y esas imágenes encuentran muchas veces destinatarios distintos a los originales. Las fotografías de Evan Baden muestran las paradojas de la sexualidad contemporánea, el deseo de un intercambio erótico más libre, pero la objetificación recurrente de lo femenino, el deseo de crear lazos íntimos, pero la superficialidad de la intimidad en la web, la búsqueda de convertirnos en sujetos públicos, reconocidos por todos, de crear una sociedad de disfrute, pero los tabúes sociales que aun se imponen marginando a los sujetos que muestran su desnudez en la web, el doble juego del capitalismo que impulsa la avidez sexual mientras al mismo tiempo critica la promiscuidad. La sexualidad actual es un terreno vasto de exploración y la web, se ha convertido en una gran fuente de información para rastrear los cambios que se dan en la sociedad actual. 


\section{FUENTES REFERENCIALES}

BAUDRILLARD, Jean. La transparencia del mal. Ensayo sobre los fenómenos extremos. Joaquin Jordá (trad.) primera edición. Barcelona, Anagrama, 1991, ISBN 84-339-1345-X.

RIVERA, Garza Ciristina. El escritor en Cyberia [en línea]México, Revista literaria Azul@rte, 20 de Noviembre de 2011 [ref. 20 de abril de 2015]. Disponible en web: http://revistaliterariaazularte.blogspot.mx/2011/11/cristina-rivera-garza-el-escritor-en.html

SENNETT, Richard, 1978, El declive del hombre público, Gerardo Di Masio (trad.) Primera Edición, Barcelona, Ediciones península, 1978, ISBN 84-297-1445-6.

STADLER, Felix, Autonomía y control en la era de la posprivacidad, Tintank, Publicado primero en Open. Cahier on Art and the Public Domain. \# 19: Beyond Privacy. New Notions of the Private and Public Domains.[Ref. 20 septiembre 2014] Disponible en: http://www.tintank.es/?author=1 